A R T I G O

\title{
VISUALIDADE E ADMINISTRAÇÃO DO TRABALHO ESCRAVO NAS FAZENDAS DE CAFÉ E ENGENHOS DE AÇÚCAR DE BRASIL E CUBA, C.1840-1880
}

\author{
Visuality and Slave Management in the Brazilian and Cuban \\ Coffee and Sugar Plantations, c.1840-1880 \\ Visualidad y administración del trabajo esclavo en las haciendas \\ de café e ingenios de azúcar de Brasil y Cuba, h.1840-1880
}

\section{RAFAEL DE BIVAR MARQUESE ${ }^{*}$}

DOI: http://dx.doi.org/10.1590/S2178-14942019000100008

I Universidade de São Paulo (FFLCH/USP) São Paulo - SP, Brasil.

*Professor titular do Departamento de História da Faculdade de Filosofia, Letras e Ciências Humanas da Universidade de São Paulo. (FFLCH/USP) (marquese@usp.br), ORCID iD: https://orcid.org/0000-0002-5566-3579

Agradeço os comentários de Leonardo Marques a uma versão anterior desse artigo, bem como a Dale Tomich, Reinaldo Funes e Carlos Venegas pelo nosso trabalho conjunto. Agradeço também aos dois pareceristas anônimos da Estudos Históricos, que me ajudaram a melhorá-lo. 0 artigo contou com financiamento do Conselho Nacional de Desenvolvimento Científico e Tecnológico (CNPq) por meio de uma bolsa de Produtividade 1-D.

Artigo recebido em 14 de outubro de 2018 e aceito para publicação em 12 de fevereiro de 2019. 


\title{
RESUMO
}

O objetivo deste artigo é compreender como os novos mecanismos de administração do trabalho escravo elaborados nas fronteiras açucareiras e cafeeiras de Cuba e do Brasil do século XIX se relacionaram com uma nova visualidade da escravidão. 0 artigo argumenta que é possível identificar um feixe de novas estratégias mobilizadas para extrair mais trabalho dos escravos, nos cafezais e canaviais do Brasil e de Cuba, como resposta à reorganização da economia-mundo sob a égide do capitalismo industrial e aos novos padrões de resistência escrava. Essas estratégias podem ser concebidas como parte de um novo regime visual da escravidão negra nas Américas.

PALAVRAS-CHAVE:Escravidão; Visualidade; Café; Açúcar; Brasil; Cuba.

\begin{abstract}
The aim of the present article is to understand how the new mechanisms of slave management developed in the Cuban and Brazilian sugar and coffee frontiers during the $19^{\text {th }}$ century were connected to a new visuality of slavery. The argument is that it is possible to identify a cluster of new strategies to extract more labor from slaves in the coffee and sugar cane plantations of Brazil and Cuba, which was a response not only to the major reorganization of the world economy under industrial capitalism but also to new patterns of slave resistance. Those strategies can be conceived as part of a new visual regime of New World slavery.
\end{abstract}

KEYWORDs:Slavery; Visuality; Coffee; Sugar; Brazil; Cuba.

\section{RESUMEN}

El objetivo de este artículo es comprender como los nuevos mecanismos de administración del trabajo esclavo desarrollados en las fronteras azucareras y de la caficultura de Cuba y de Brasil del siglo XIX se relacionaron con una nueva visualidad de la esclavitud. El artículo argumenta que es posible identificar un grupo de nuevas estrategias movilizadas para extraer más trabajo de los esclavos, en los cafetales y cañaverales de Brasil y de Cuba, como respuesta a la reorganización de la economía-mundo bajo la égida del capitalismo industrial y a los nuevos patrones de resistencia esclava. Se puede concebir esas estrategias como parte de un nuevo régimen visual de la esclavitud negra en las Américas.

Palabras-Clave:Esclavitud; Visualidad; Café; Azúcar; Brasil; Cuba. 
I.

companhando o movimento geral da chamada "virada visual" nas ciências sociais, a
cultura visual da escravidão negra nas Américas é um assunto que gerou boa fortuna crítica nas últimas duas décadas. De fato, hoje dispomos de um número considerável de estudos sobre as múltiplas formas de representação visual da escravidão do Novo Mundo. Com base em enfoques e perspectivas teóricas diversas, esses trabalhos ajudaram a iluminar os meios pelos quais a escravidão negra foi apreendida visualmente nos embates sociais e políticos que disputaram sua legitimidade a partir do final do século XVIII; como a cultura visual da escravidão se articulou ao nascimento da sociedade de consumo e à cultura do refinamento; como foram representados, a partir de distintos suportes, os ambientes construídos rurais e urbanos em que viveram os sujeitos escravizados; e quais foram os desdobramentos do arquivo visual da época da escravidão para a política da memória no tempo presente (Wood, 2000; ibidem, 2013; Quilley e Kriz, 2003; Kriz, 2008; Vlach, 2002; Dresser e Hann, 2013; Cauna, 2009: 21-48; Gikandi, 2011; Ellis e Ginsburg, 2010; Slenes, 2002; Lima, 2007; Sela, 2008; Koutsoukos, 2010; Beltramin, 2013; Araújo, 2010; ibidem, 2014).

Tais pesquisas muito contribuíram para o entendimento das formas pelas quais a escravidão negra foi representada em diferentes tempos e espaços. Em alguns casos, os pesquisadores foram particularmente felizes em conjugar o exame das representações visuais com a análise dos efeitos que elas produziram sobre o mundo social em que se inscreveram (Mclnnis, 2005; 2012). Os estudos disponíveis, no entanto, pouco se preocuparam em perscrutar como o vasto repertório visual do mundo da escravidão se relacionou concretamente com a exploração do trabalho escravo. ${ }^{1}$

Neste artigo, procurarei preencher tal lacuna ao examinar duas zonas de ponta da escravidão negra do século XIX: a região ocidental de Cuba, especializada na produção açucareira, e o vale do rio Paraíba do Sul, o grande centro de produção de café no Brasil oitocentista. Não obstante as particularidades de cada qual, a formação desses espaços pode ser conceituada a partir do processo unificado que foi denominado por Dale Tomich e por outros historiadores como a "segunda escravidão" do mundo atlântico (Tomich, 2004: 56-71; Marquese e Salles, 2016). 0 conceito tem gerado uma boa fortuna na historiografia relativa à economia e à sociedade algodoeiras do Sul dos Estados Unidos (Kaye, 2009; Dal Lago, 2012; Baptist, 2014; Beckert, 2014). 0 mesmo pode ser dito sobre Brasil e Cuba. Temos à disposição estudos comparativos sobre esses dois espaços - eventualmente incorporando também os Estados Unidos - que tratam das ideias sobre a administração de escravos, da política da escravidão, do tráfico transatlântico, da escravidão urbana, do ordenamento e das práticas jurídicas, 
da ciência e da técnica escravistas (Marquese, 2004; Marquese, Parron e Berbel, 2016; Blackburn, 2011; Schmidt-Nowara, 2011; Parron, 2015; Marques, 2016; Santos, 2012; Silva Jr., 2015; Rood, 2017).

Valendo-me da perspectiva analítica da segunda escravidão, cujas linhas de força serão explicitadas a seguir, meu objetivo neste artigo é voltar-me ao exame de um conjunto de fontes visuais relativas aos espaços de plantation das novas zonas escravistas de Cuba e Brasil, com o propósito de compreender como os novos mecanismos de administração do trabalho escravo elaborados em suas fronteiras açucareiras e cafeeiras se relacionaram com uma nova visualidade da escravidão. Ao fazê-lo, pretendo dialogar com autores que recentemente escreveram sobre temas correlatos para o Sul algodoeiro (Baptist, 2014: 111-144; Johnson, 2013: 151-175), mas que não se valeram de registros visuais para a construção de suas análises. Para tanto, o artigo está dividido em três partes. Na primeira, apresento brevemente o processo de formação recíproca, via mercado mundial, das novas zonas açucareiras e cafeeiras em Cuba e no Brasil, e o aparecimento, nessas regiões, de novas unidades produtivas nas décadas de 1830 e 1840, cujas plantas romperam com os padrões anteriormente vigentes no mundo atlântico. Na segunda e na terceira parte, analiso os novos mecanismos visuais empregados para a exploração do trabalho escravo e da natureza nessas novas plantations açucareiras e cafeeiras. 0 argumento que pretendo desenvolver é o de que, após as décadas de 1830 e 1840, é possível identificar um feixe de novas estratégias mobilizadas para extrair mais trabaIho dos escravos nos cafezais e canaviais do Brasil e de Cuba, que devem ser concebidas como parte de um novo regime visual da escravidão negra nas Américas.

II.

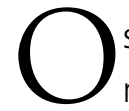

s primeiros engenhos de açúcar brasileiros e cubanos foram fundados ainda no primeiro século da exploração europeia do Novo Mundo. Antes da segunda metade dos setecentos, contudo, Cuba, com suas unidades em pequena escala concentradas nos arredores de Havana, ocupou lugar insignificante no mercado mundial. Pernambuco e Bahia se destacaram como produtores de vulto já na passagem do século XVI para o XVII, mas, entre 1660 e 1760, as duas capitanias açucareiras da América portuguesa perderam espaço no mercado mundial para a pujante indústria açucareira das Antilhas britânicas e francesas. Como resultado das políticas de estímulo promovidas pelas reformas ilustradas ibéricas, a partir da década de 1770 houve acentuado crescimento das exportações açucareiras do Brasil (que contava agora com o produto das capitanias do Rio de Janeiro e de São Paulo) e do ocidente 
de Cuba, movimento que recebeu impulso renovado com a eclosão da revolução escrava na colônia francesa de Saint-Domingue. Quanto ao café, antes da década de 1790 as exportações cubanas e brasileiras foram virtualmente inexistentes. Somente as colônias francesas, holandesas e, em escala bem menor, britânicas exportavam café, sendo a posição principal ocupada por Saint-Domingue, responsável por cerca de 50\% da oferta mundial do artigo em 1790, com um volume total de 34.650 toneladas (Piqueras, 2014: 97-144; Schwartz, 1988: 144-176; 337-355; Marquese, 2013: 293-297).

A partir de 1790, Brasil e Cuba tiveram seus destinos açucareiros e cafeeiros entrelaçados de forma estreita. No plano imediato, o início da Revolução do Haiti estimulou o rápido avanço da produção açucareira, lastreada no aumento do tráfico negreiro transatlântico. Entre 1790 e 1820, a exportação açucareira combinada das diversas capitanias da América portuguesa cresceu de 13 mil para 35 mil toneladas; os desembarques decenais de africanos escravizados saltaram de cerca de 190 mil indivíduos, na década de 1780, para 451 mil, na década de 1810 (é importante destacar que a economia colonial brasileira verificou grande diversificação em sua pauta de exportações, com destaque para o algodão). Em (uba, o salto foi ainda mais impressionante: de 15 mil para 55 mil toneladas de açúcar exportadas, com a importação de cerca de 15 mil escravos na década de 1780, e 115 mil na década de 1810. Na produção de café, as curvas de crescimento foram semelhantes: partindo de um volume praticamente nulo em 1790, em 1821, Brasil e Cuba exportavam, respectivamente, 13.500 e 10 mil toneladas de café2 (Moreno Fraginals, 1989, v. 2: 355; Arruda, 1986: 234; Marquese, 2013: 297-298).

De 1820 em diante, alimentados por um gigantesco tráfico negreiro transatlântico (entre 1821 e 1860, os dois espaços juntos importariam mais de 1,77 milhão de africanos escravizados), Cuba e Brasil lograram impor-se como os maiores produtores mundiais de açúcar e de café. Com a independência do Haiti, as possessões francesas produtoras de açúcar/café foram drasticamente reduzidas. As Antilhas britânicas, acuadas pelo movimento antiescravista metropolitano que interditara o tráfico transatlântico em 1807, e com a deriva dos interesses imperiais para o espaço do Índico, rapidamente perderam o pé da competição com suas rivais no espaço americano. Mas o mais interessante a registrar é como a reorganização do mercado mundial após a década de 1820 conduziu a uma crescente especialização de Cuba no açúcar e do Brasil no café. Veja-se, para efeitos de comparação, a trajetória desses dois produtos nesses dois espaços. 
Tabela 1: Médias quinquenais de exportação de café e açúcar em toneladas, 1821-1860.

\begin{tabular}{|l|l|l|l|l|}
\hline & \multicolumn{2}{|c|}{ AçúCAR } & \multicolumn{2}{c|}{ CAFÉ } \\
\hline & Brasil & Cuba & Brasil & Cuba \\
\hline $1821-1825$ & 41.400 & 63.100 & 14.060 & 10.900 \\
\hline $1826-1830$ & 54.800 & 84.130 & 25.680 & 19.340 \\
\hline $1831-1835$ & 69.600 & 101.400 & 53.320 & 22.400 \\
\hline $1836-1840$ & 81.600 & 129.800 & 71.020 & 21.180 \\
\hline $1841-1845$ & 88.600 & 170.400 & 88.260 & 15.020 \\
\hline $1846-1850$ & 117.800 & 253.400 & 124.900 & 8.680 \\
\hline $1851-1855$ & 123.800 & 389.600 & 153.800 & 6.180 \\
\hline $1856-1860$ & 105.800 & 435.200 & 168.500 & 4.200 \\
\hline
\end{tabular}

Fontes: Moreno Fraginals, 1989, v. 2: 355-357 (açúcar em Cuba); IBGE, 1987: 342 (açúcar no Brasil); Samper e Fernando, 2003: 428-433 (café). Nota: Números arredondados.

Se no início do período em tela os volumes de açúcar e de café remetidos por Brasil e Cuba ao mercado mundial eram relativamente equiparáveis, ao final dele a discrepância era evidente. 0 volume das exportações cubanas no quinquênio 1856-1860 equivalia a 25\% da produção mundial de açúcar (cana e beterraba somadas); as exportações brasileiras de café foram responsáveis, nessa mesma quadra, por $52 \%$ da oferta ao mercado mundial. Mas o que se destaca é a tendência à estagnação do açúcar brasileiro em 1840-1860, quando as exportações de Cuba triplicaram. Algo semelhante, porém em sinal trocado, aconteceu com o café: o volume brasileiro mais do duplicou entre 1840 e 1860, enquanto o de Cuba encolheu quatro vezes, sendo, em 1860, menos da metade do que havia sido em 1820.

Resta indagar se esses movimentos tiveram relação. A resposta é positiva. Em um regime de livre competição internacional, a eficácia dos senhores de engenho cubanos em enfrentar as condições adversas do mercado mundial, ofertando um produto crescente a baixo custo, alterou as condições de operação de seus rivais. Mesmo que a produção brasileira de açúcar tenha crescido entre 1820-1860, ela foi incapaz de acompanhar o ritmo de Cuba. Sem o concurso do tráfico negreiro transatlântico, encerrado em 1850, a produção brasileira de açúcar diminuiu; antigas áreas açucareiras, como o Oeste de São Paulo, foram convertidas para a produção cafeeira. No reverso da moeda, o avanço da produção cafeeira do Brasil foi um vetor decisivo para a crise da cafeicultura em Cuba. Em 1830, engenhos e cafezais cubanos empregavam um número equivalente de escravos, cerca de 50 mil cada. Diante da ineficácia da cafeicultura cubana face ao Brasil, houve, nas décadas de 1830 e 1840, um deslocamento massivo de escravos em Cuba dos cafezais para os canaviais, movimento que por sua vez foi 
importante para o salto açucareiro da ilha - e, portanto, para a própria estagnação da produção de açúcar no Brasil (Marquese e Tomich, 2009: 339-383).

Uma das razões para as trajetórias divergentes, porém mutuamente condicionadas, de Brasil e Cuba residiu nas condições geoecológicas de produção, isto é, nos diferenciais de altitude, clima e produtividade do solo, que tornavam cada zona mais adequada para tal ou qual artigo. Porém, para que os potenciais açucareiro, do ocidente de Cuba, e cafeeiro, do Vale do Paraíba, se realizassem plenamente, transcorreu um período considerável de experimentação, até que se cristalizasse uma nova forma de configuração espacial da plantation escravista. Noutros termos, o salto cafeeiro do Brasil e açucareiro de Cuba em grande parte foi caudatário de uma nova planta produtiva que apareceu justamente nas décadas de 1830 e 1840. Lastreada na importação maciça de africanos e na abertura de zonas de fronteira agrícola até então despovoadas - ou ocupadas por posseiros e pequenos proprietários cujos modos de vida tradicionais foram varridos pela força do capital -, essa planta rompeu com os padrões anteriormente vigentes no Caribe britânico e francês (Funes e Tomich, 2009: 75-117; Piqueras, 2014: 171-186; Marquese, 2009: 215-252).

Mais amplos, mais capitalizados, empregando um número maior de escravos, as fazendas de café do Vale do Paraíba e os engenhos de açúcar do ocidente de Cuba promoveram uma substantiva concentração da propriedade escrava e da estrutura fundiária. A configuração espacial dessas novas plantations teve que enfrentar um novo quadro na luta entre senhores e escravos, entre as forças escravistas e as forças antiescravistas, tanto no plano local quanto no plano global. A introdução massiva de africanos em Cuba e no Brasil se deu sob o signo da ilegalidade (o tráfico transatlântico de escravos fora formalmente proibido para os dois países em 1820 e 1831), sempre a contrapelo da fortíssima pressão diplomática da Grã-Bretanha. A profunda alteração da demografia do campo cubano colocou a colônia espanhola sob o risco permanente de revoltas escravas em larga escala, que não deixaram de pontear a zona ocidental entre 1825 e 1844. Os senhores de escravos do Brasil lidaram com problema semeIhante, ainda que não na intensidade do que se passou em Cuba (Marquese, Parron e Berbel, 2016; Barcia Paz, 2008; Gomes, 2006: 144-247; Grinberg, Salles e Borges, 2009: 235-270).

Portanto, a resistência escrava deve ser considerada parte estruturante da formação dessas duas novas zonas escravistas e de suas respectivas unidades produtivas. Como aumentar a exploração do trabalho escravo, em engenhos e fazendas com escala inédita, sem colocar a perder todo o edifício escravista? 0 restante do artigo argumentará que parte da resposta pode ser encontrada no novo mecanismo de funcionamento do olho senhorial-escravista - ou seja, em uma nova visualidade da escravidão. 
III.

ntre março de 1855 e fevereiro de 1857, foi impressa na tipografia havanesa de Louis Marquier, francês há dez anos residente em Cuba, o que certamente é a mais incrível série de litografias sobre as plantations escravistas do Novo Mundo. Preparadas por Eduardo Laplante (outro francês que se mudara para Cuba no final da década de 1840 como representante da firma de maquinário açucareiro Derosne \& Cail, e que logo começou a trabalhar também como litógrafo para a indústria tabaqueira local), com textos explicativos de Justo Cantero (poderoso senhor de engenho em Trinidad, na costa sul da ilha, com formação em medicina nos Estados Unidos), essa série compunha um total de 28 estampas em cores iluminadas uma a uma, acrescidas de 4 plantas arquitetônicas de engenhos e 4 plantas de maquinário das moendas, caldeiras e centrífugas. Para a preparação desse material, Laplante e Cantero visitaram 25 engenhos do ocidente de Cuba, a maior parte dos quais situados na planície de Colón, zona de Matanzas-Cárdenas. A seleção obedeceu a um critério preciso: salvo uma ou outra exceção, essas eram unidades produtivas escravistas de ponta, que permitiam expor ao consumidor das vistas e textos a diversidade de soluções técnicas empregadas pelos engenhos mais avançados de Cuba. Concebido como um veículo para a construção da identidade de classe da sacarocracia cubana na conjuntura crítica dos anos 1850, o projeto editorial representava em composição luxuosa a economia escravista da ilha no seu ponto máximo de desenvolvimento produtivo e tecnológico.3

Um dos engenhos visitados por Laplante/Cantero foi o Purísima Concepción, localizado em Banagüises, a norte de Colón (figura 1). 


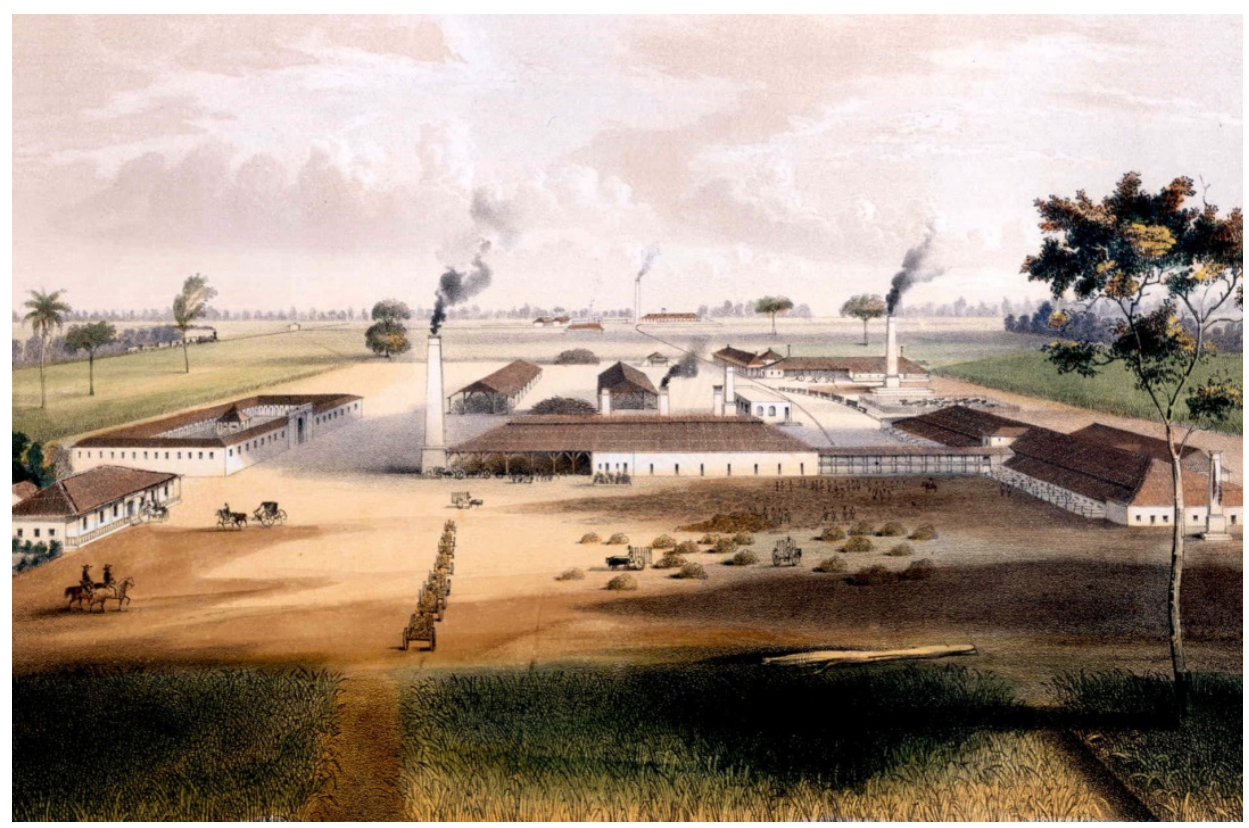

Figura 1: Eduardo Laplante (lit.), Ingenio Purísima Concepción (a) Echeverría, propiedad de la sra. da. Francisca Pedroso y Herrera, 1857 [lit. aquarelada, imagem original 36,5 x 23,8 cm] (Cantero, 2006: 236).

0 engenho começara a ser montado em 1847, entrando em produção plena a partir de 1851. Quanto da elaboração da litografia, suas dimensões eram de 91 caballerías de terra (251 alqueires geométricos), das quais 40 (110 alqueires) plantadas com cana. Residiam no engenho 362 escravos e 50 trabalhadores asiáticos sob o regime de servidão temporária por contrato. 0 potencial de safra estimada era de 117 mil arrobas de açúcar. 0 engenho contava com seis trens jamaicanos e suas correspondentes clarificadoras, tratando-se, portanto, de uma unidade semimecanizada ao combinar moendas de ferro movidas a vapor com caldeiras abertas. Porém, um dos elementos que o particularizavam era sua integração, via trilhos internos, com outra unidade açucareira, o engenho San Martín. Na litografia, este segundo engenho fornece o ponto de fuga da composição; ao centro da imagem, observam-se claramente os trilhos que conectam a casa de moendas/caldeira do Purísima Concepción com o batey (termo que denomina a sede da plantation, com todas as instalações produtivas e moradias de trabalhadores) de sua unidade irmã. No plano do batey de San Martín preparado por Laplante (figura 2), nota-se como os trilhos articulavam diretamente as duas fábricas (o ramal à direita conectava o engenho ao ramal do caminho de ferro que ligava Banagüises à baia de Cárdenas; trata-se da mesma linha de ferro representada à esquerda da litografia do Purísima 
Concepción). A escala de San Martín era ainda mais grandiosa: completamente mecanizado, isto é, com moenda a vapor, caldeiras a vácuo e centrífugas, força de trabalho composta por 452 escravos e 125 trabalhadores asiáticos sob servidão temporária, e 55 caballerías plantadas com cana (de um total de 222 caballerías), a safra estimada por Cantero para 1855 seria de 273 mil arrobas de açúcar.

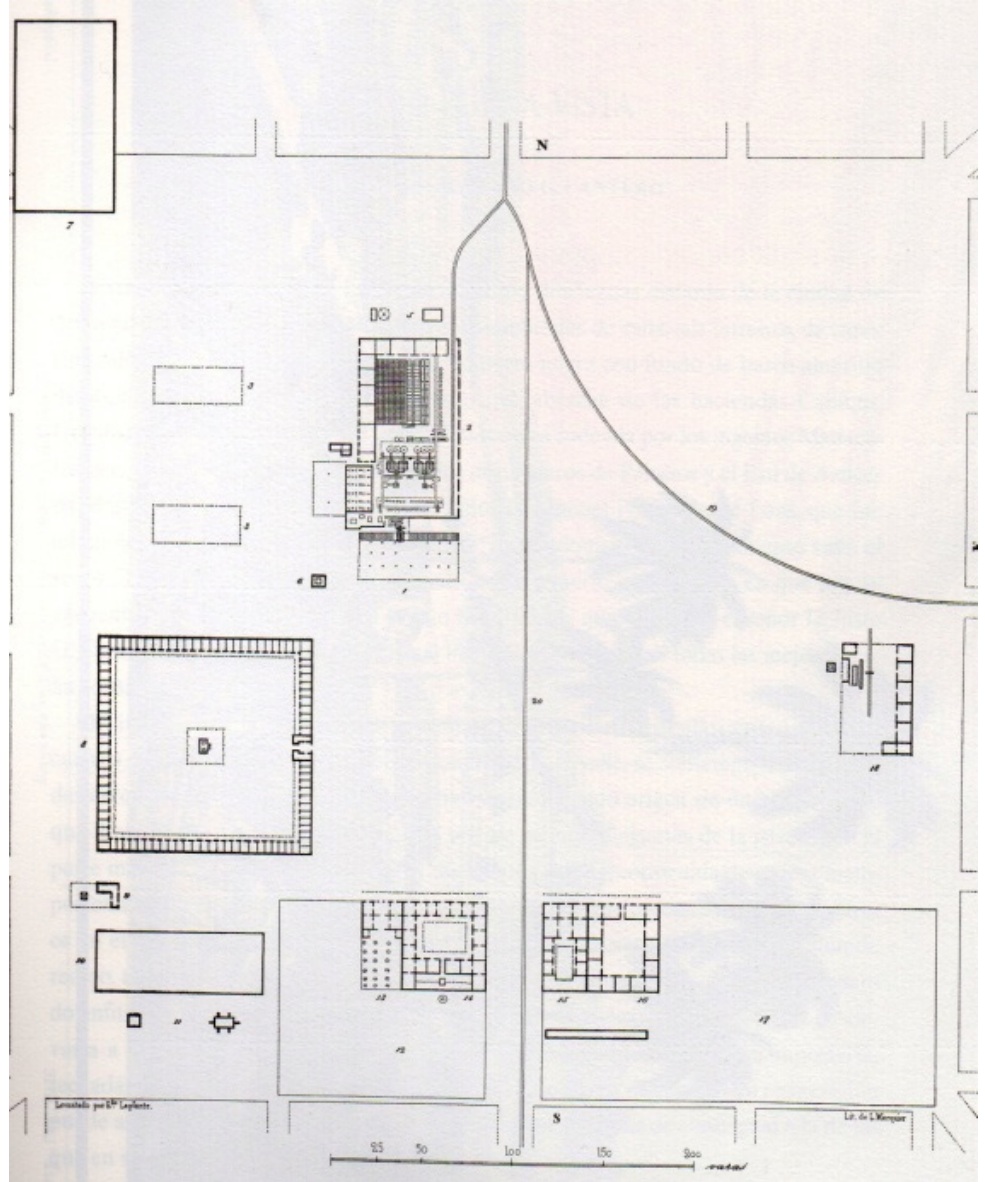

Figura 2: Eduardo Laplante (lit.), detalhe do Plano de las fábricas del Ingenio San Martín, propiedad de la sra. da. Francisca Pedroso y Herrera, 1857 [imagem original 36,5 x 23,8 cm] (Cantero, 2006: 199).

Portanto, somadas as duas unidades, o complexo contaria com um total de $100 \mathrm{ca}$ ballerías plantadas com cana e 989 trabalhadores, capazes de produzir 390 mil arrobas de açúcar. Uma rápida comparação da relação área plantada em canco/trabalhadores/produção 
de açúcar/escravo mostra como Cuba rompera com o padrão anteriormente vigente no Caribe. Na Jamaica e em Saint-Domingue na virada do século XVIII para o XIX, a proporção girava em torno de 1,20 a 1,50 acres plantados com cana por trabalhador residente no engenho; nas 25 unidades visitadas por Laplante e Cantero, essa proporção era de 3,85 acres por trabalhador. Quanto à produção de açúcar por escravo, em 1861 se obtinha em Cuba o triplo de suas rivais caribenhas na década de 1790 (Higman, 1995: 163; Bonnet, 2008: 127; García Mora e Santamaria García, 2006: 44; Piqueras, 2014: 179, gráfico 5). A junção de duas unidades com o porte do Purísima Concepción/San Martín em um único complexo articulado por trilhos internos ainda era pouco usual na década de 1850. Tampouco os engenhos completamente mecanizados - como San Martín - constituíam a regra: em 1860, eles eram apenas 4,86\% das unidades açucareiras de Cuba, responsáveis, naquele ano, por $14,80 \%$ da produção total da ilha. 0 perfil dominante da indústria açucareira cubana aproximava-se mais do caso do engenho Purísima Concepción, isto é, das unidades semimecanizadas, que englobavam 67,45\% dos engenhos da ilha, responsáveis por 76,62\% da produção total em 1860 (Idem: 180).

Uma questão básica se apresenta a partir desses dados: diante da escala humana e espacial dos engenhos cubanos, como administrá-los com eficácia? As demandas de organização do trabalho e da produção das plantations açucareiras do Novo Mundo há muito as colocavam na linha de frente das práticas administrativas da economia-mundo capitalista (Marquese, 2004: 71-80; 162-165; 377-379). As novas dimensões dos engenhos cubanos, todavia, com centenas de escravos (em sua maioria africanos) sendo compelidos a cumprir uma carga inaudita de trabalho, em uma conjuntura de profunda tensão nas relações escravistas, exigiam novas soluções administrativas.

As próprias imagens de Laplante nos ajudam a entender como se resolveu o problema, a começar pelo padrão de moradia escrava. Na paisagem do engenho Purísima Concepcíon observa-se, à esquerda da casa de moagem/caldeiras, um grande edifício retangular, com entrada única e pequenas janelas gradeadas. 0 programa arquitetônico dessa edificação fica mais evidente se observarmos sua congênere na planta do engenho San Martín, isto é, a grande construção quadrangular à esquerda, o maior edifício do batey, novamente com entrada única, tendo todos os seus cem cubículos voltados a um pátio interno. Trata-se do famoso barracón, modelo de moradia escrava que foi concebido em meados da década de 1820 como resposta dos poderes escravistas cubanos aos levantes escravos que pontilharam o ocidente da ilha naquela ocasião, e que se disseminaria nos grandes engenhos semimecanizados no começo da década de 1840, no quadro imediato da repressão à vasta articulação para um levante escravo envolvendo diversas plantations da zona de Matanzas-Cárdenas - a chamada "Conspiração de la Escalera" (Marquese, 2005: 175-185). 
0 objetivo imediato do barracón, portanto, era garantir o estrito confinamento noturno dos escravos, para impedi-los de contatar seus parceiros de cativeiro nas plantations vizinhas. Mas, além desse propósito de controle espacial, decorrente da necessidade de permanente visualização dos escravos, havia outro, derivado das imposições do processo produtivo dos engenhos cubanos. Como se sabe, a produção de açúcar exige estrita coordenação entre a esfera agrícola e a manufatureira: depois de cortada, a cana deve ser moída em 24 horas, caso contrário seu caldo não se cristalizará. Quanto mais produtiva é a manufatura e mais ampla a área plantada, maiores são os problemas de coordenação das duas esferas e, portanto, de coordenação do trabalho coletivo. 0 caráter prisional/militarizado dos barracones era um importante instrumento para regular de forma estreita, por meio de rígidos protocolos de visibilidade que restringiam brutalmente a autonomia escrava, o tempo de descanso e a arregimentação das turmas de trabalho para as diferentes tarefas do ciclo de produção (Marquese, 2004: 314-327; Tomich, 2009: 133-150). Essas necessidades de confinamento e coordenação também ajudam a explicar a divisão do complexo Purísima Concepción-San Martín em duas unidades distintas, porém articuladas. Os trilhos internos permitiam que a matéria-prima (cana cortada, porém não moída; açúcar a ser purgado etc.) pudesse ser rapidamente transferida de uma para outra unidade, dando vazão ao fluxo do processo de produção. Integrá-las em um único batey traria enormes problemas para a gestão do trabalho (como o confinamento de um milhar de escravos) e da produção (tempo excessivo de deslocamento dos escravos dos barracones para o campo; volume muito grande de matéria-prima a ser processada).

Isso nos traz de volta ao problema da escala dos engenhos. Como se leu no parágrafo anterior, as dimensões da área cultivada com cana eram determinadas pela capacidade de processamento na manufatura. A crescente mecanização dos engenhos cubanos exigiu a ampliação dos campos em cultivo, com a consequente ampliação da força de trabalho (o novo maquinário poupava mão de obra, e, portanto, permitia o deslocamento de mais escravos para o campo, mas isso era insuficiente). A gestão dos engenhos semimecanizados e mecanizados cubanos, assim, precisava dar conta do manejo de canaviais cada vez mais vastos e, em especial, da aceleração do ritmo de corte para manter o novo maquinário em níveis ótimos de operação (Tomich, 2009: 136-138). Esse sentido de movimento contínuo, aliás, foi o que deu a tônica da organização visual da litografia de Laplante: movimento das carretas de cana e da composição ferroviária, ambas moduladas pelo eixo diagonal do ponto de fuga da imagem; movimento das moendas e das caldeiras (registrado pela operação das chaminés das máquinas a vapor); e movimento dos escravos dispondo lenha para as fornalhas. 
E é igualmente nesse sentido de movimento que se encontra outra dimensão importante da nova visualidade da gestão do trabalho escravo. Historicamente, o trabalho escravo nas operações de cultivo e corte da cana sempre foi organizado de acordo com o chamado gang system, ou seja, turmas de escravos trabalhando em uníssono sob o comando unificado do feitor (Morgan,: 1988; 189-220; Marquese, 2004: 71-75). Em Cuba, esse sistema era chamado de cuadrillas. Mas as demandas impostas pela nova escala espacial do engenho cubano exigiram algumas modificações no sistema anteriormente empregado nos engenhos ingleses e franceses. Na litografia do engenho Santa Teresa, uma unidade completamente mecanizada montada em fins da década de 1840 em Colón, com 60 caballerías com cana e uma força de trabalho total com 380 escravos, Laplante deu a ver no que consistia o padrão cubano de organização das cuadrillas (figura 3). 0 artista francês expressou aqui a conexão estreita entre cuadros (talhões) de cana, as guardarrayas (os caminhos para os carros de bois, que também separavam os cuadros de cana) e os carretones (carros de boi). Vemos, à direita, uma cuadrilla com 25 escravos, sob o comando de um capataz (contramayoral) a cavalo - possivelmente, acompanhado por um mayoral (feitor), também a cavalo -, cortando cana. As guardarrayas estão no eixo diagonal à esquerda, articulando o campo ao batey. Um olhar mais próximo dos carrretones (algo que também vale para a linha de sete carros que pode ser vista entrando no batey do Purísima Concepción) permite observar a uniformidade desses veículos, construídos para carregar cada qual 100 arrobas de cana cortada (Zayas, 1836: 174; Moreno Fraginals, 1989, v. 1: 244, 27n).

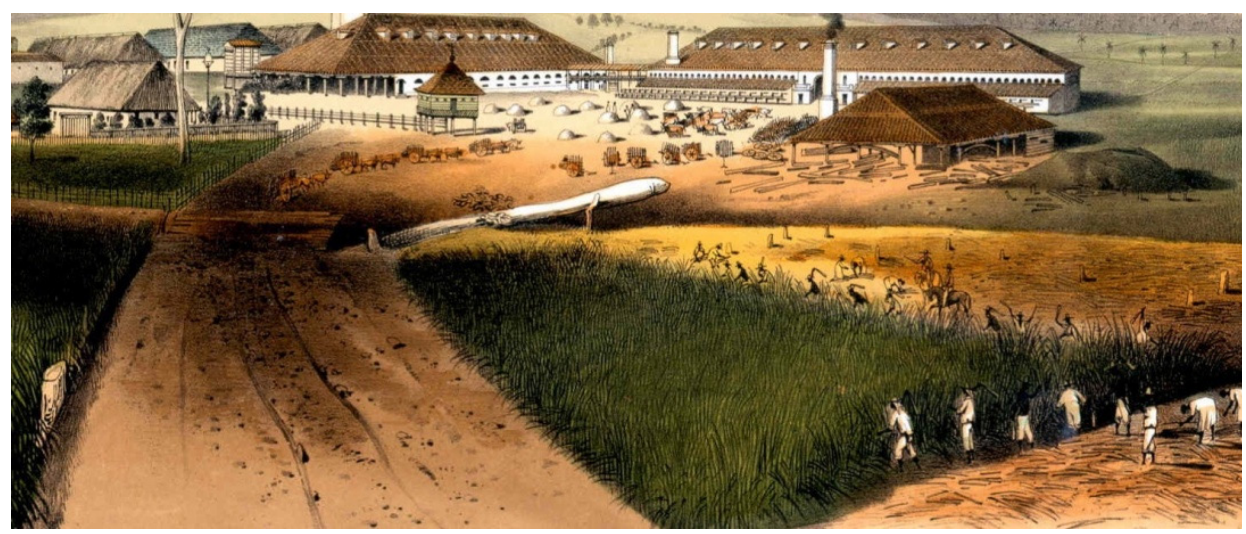

Figura 3: Eduardo Laplante (lit.), detalhe do Ingenio Sta. Teresa (a) Agüica, propiedad del excmo. sr. conde de Fernandina, 1857 [lit. aquarelada, imagem original 36,5 x 23,8 cm](Cantero, 2006: 128). 
A topografia plana da zona de Matanzas/Cárdenas/Colón facilitava a imposição de um novo padrão de trabalho ao sistema de cuadrillas,por meio do estabelecimento de uma rigorosa regularidade de plantios, caminhos e carros, em uma paisagem geometrizada. 0 andamento do processamento na fábrica demandava um controle preciso da quantidade de matéria-prima: daí a importância da estandardização dos carros e da quantidade de cana em cada qual. Mas, sem uma exata representação do campo, de nada adiantaria essa regularidade. A composição de mapas tornou-se peça essencial para as operações dos engenhos, e os manuais agronômicos cubanos não se furtaram a apresentar modelos para a sua elaboração. ${ }^{4}$

Temos um bom exemplo dessa prática cartográfica no mapa do ingenio Merced, composto em 1863 (figura 4). 0 engenho, semimecanizado, foi fundado em 1856, também na região de Colón. Em 1860, apenas 22 de suas 50 caballerías estavam ocupadas com cana; conforme o censo agrícola de 1877, suas dimensões haviam sido então ampliadas para um total de 70 caballerías, das quais 40 com cana, com uma força de trabalho de 283 escravos e 83 "asiáticos" (García Mora e Santamaria García, 2006, apêndice I: 314; ibidem, 2006, apêndice II: 380). Como se pode verificar pela sua fatura, o mapa foi claramente composto para fins de controle do processo de trabalho. Inserido dentro de um livro contábil, ele permitia rápida visualização de todo o espaço do engenho (batey, guardarrayas, cuadros de cana, pastos, bananal etc.) 0 plano do engenho cumpriu à risca as recomendações de simetria prescritas pela literatura agronômica coeva, com o batey situado exatamente no centro da propriedade. ${ }^{5}$ 


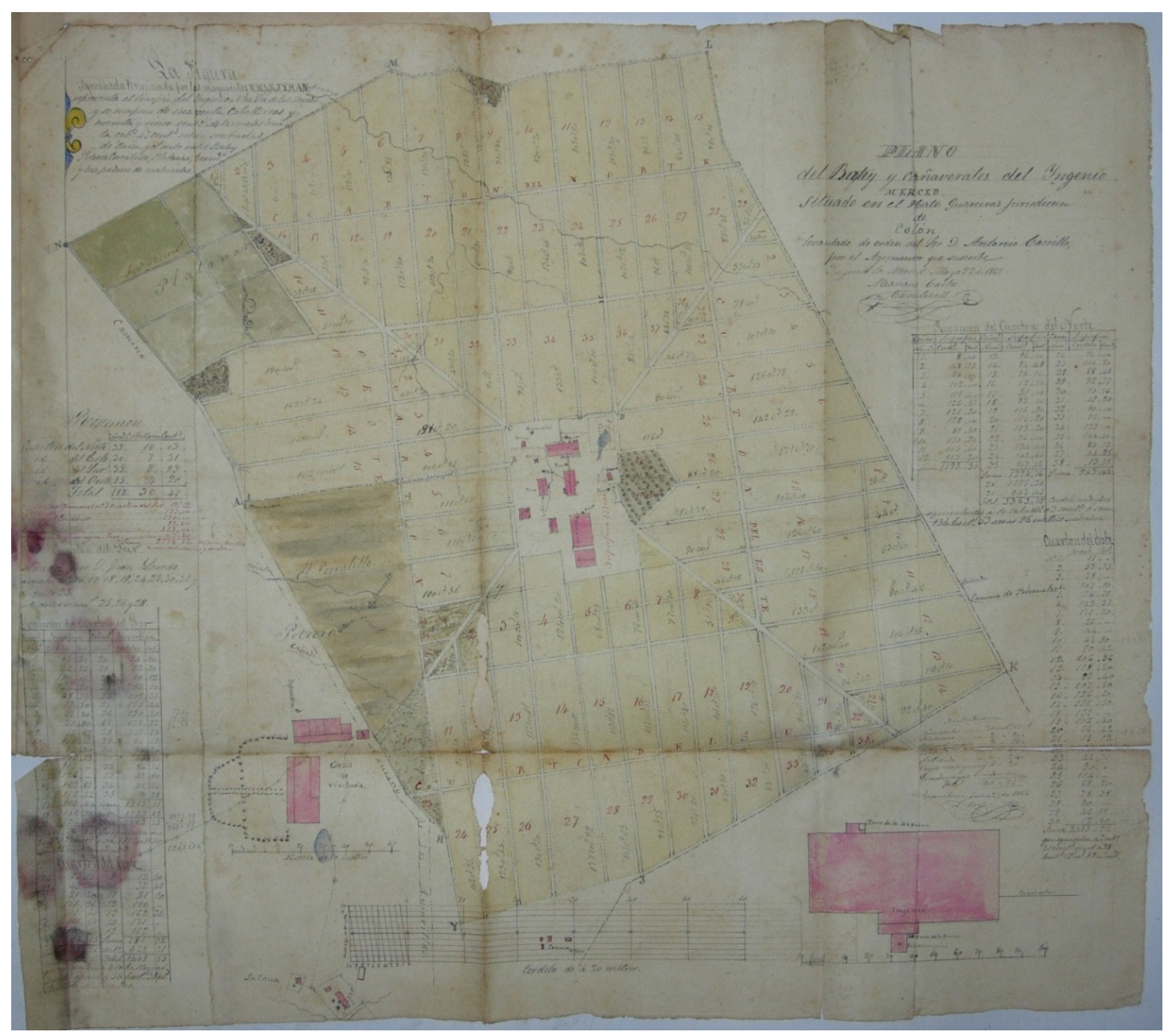

Figura 4: Plano del batey y cañaverales del ingenio Merced. Fondo Serafín Sánchez Govín, Fundación Antonio Nuñez Jimenez de la Naturaleza y el Hombre, Habana, Cuba.

A novidade do sistema de cuadrillas cubano se inscreve na própria disposição espacial representada por esse mapa. Ao contrário do Caribe, onde as gangs de escravos eram organizadas conforme a força dos cativos, em Cuba as cuadrillas eram estruturadas a partir dos carros de boi: tempo e movimento eram os pontos-chave desse novo sistema de trabalhos por turmas (Tomich, 2009: 142-146). Cada cuadrilla era composta por uma dada proporção de cortadores de cana (macheteros, homens fortes), juntadores (alzadores, em geral mulheres) e condutores dos carros de boi (carreteros). Se o cuadro de cana (as formas retangulares, numeradas, que se pode observar no mapa de La Merced) estivesse próximo ao batey, a proporção seria de 2 cortadores/ 2 juntadores para cada condutor; 2 cuadrillas (cada qual com cerca de 35 trabalhadores e 7 carros) dariam conta do montante a ser cortado e transportado às moendas. Para os cuadros distantes, com maior demanda de carros, a proporção seria de 20 
cortadores/20 juntadores/14 condutores, modificando-se, portanto, a composição numérica das cuadrillas e a quantidade de carros mobilizados. Essas proporções, contudo, não eram fixas, pois variavam conforme a área de cada cuadro,sua distância do batey e o andamento da safra. Esperava-se que a média diária por cortador fosse de 500 arrobas de cana, ou 5 carros cheios (Landa, 1866: 48).

A litografia do Purísima Concepción (figura 1) representou a entrada de uma cuadrilla de carretas com sete peças no batey do engenho; outra deveria estar a caminho do campo. Com esse sistema de administração, capaz de extrair uma enorme carga de trabalho dos escravos por meio de uma rígida coordenação do trabalho coletivo no tempo e no espaço, os senhores cubanos lograram ampliar em muito a área cultivada com cana. Mas, se o espaço do engenho não fosse devidamente esquadrinhado, isto é, visualizado, tal engrenagem de exploração do trabalho escravo não funcionaria. Este foi o sentido da composição de mapas como o de La Merced. Com a numeração dos cuadros de cana (um total de 118, cada qual equivalente a 1 dia de corte), tal mapa permitia efetuar cálculos precisos sobre a quantidade de cana a ser cortada e, portanto, sobre a administração dos escravos no processo de produção de açúcar. $A$ relação do mapa com o processo de trabalho e o processo de produção era direta. A proporcionalidade matemática da manufatura projetava-se sobre o campo e ordenava o andamento do trabalho coletivo dos escravos. Ao mapa somava-se, ainda, um controle contábil cuidadoso da quantidade de cana que entrava diariamente na moenda; a partir dos informes diários do "capataz de las carretas", o administrador geral se encarregaria da quantificação semanal desses dados. ${ }^{6}$

Após visitar o engenho Unión, unidade mecanizada com 498 escravos, Cantero anotou que:

[...] o número total de caballerías plantadas é de 45, com a distinção de serem todos os cuadros perfeitamente regulares, formando quadrilongos de um terço de caballería, igualdade que facilita muito as operações. Este simples fato, por si só suficiente para demonstrar a inteligência dos proprietários, coincide com outro que não podemos deixar de citar para cumprir o dever de justiça. Oferecendo-nos um livro que eles mantêm e no qual anotam com escrupulosa precisão cada safra, o número total de terrenos plantados com as subdivisões correspondentes de caballerías, o número de carros de cana que cada uma delas produz, os pães de açúcar que rendem, a época em que foi plantado cada cuadro, que se distingue dos demais pela numeração etc. Com o auxílio de tão bem ordenado plano, com uma só olhada se colocam a par dos produtos comparativos dos anos que conta em existência a propriedade, e têm sempre à vista o estado em que esta se encontra. (Cantero, 2006: 184; tradução livre.). 
Com o mapa em um livro contábil, "com uma só olhada" o proprietário tomaria ciência de tudo o que se passava em seu engenho: eis uma clara expressão do regime visual da segunda escravidão, variável-chave para o sucesso da produção cubana de açúcar no mercado mundial do século XIX.

IV.

— ntre os anos 1870 e meados da década seguinte, o pintor italiano Nicolau Antonio Fac$\mathcal{L}$ chinetti, residente na Corte do Rio de Janeiro desde 1849, foi requisitado por algumas famílias de fazendeiros do Vale do Paraíba para registrar as paisagens de suas propriedades. Finalizado em abril de 1875, o óleo sobre madeira da fazenda Flores do Paraíso, localizada no município de Valença, Vale do Paraíba fluminense (atualmente Rio das Flores, Rio de Janeiro), é sem dúvida o melhor resultado dessa série. 0 quadro lhe fora encomendado por Domingos Custódio Guimarães Filho. Tendo recebido o título de segundo barão do Rio Preto em 1874, e a fazenda - como herança materna - um ano antes, com a encomenda Custódio Guimarães Filho pretendia ter nas paredes de sua residência na capital do Império do Brasil o registro visual da propriedade que tanto notabilizara sua família, a partir do pincel de um dos artistas mais requisitados de então. ${ }^{7}$

As terras que deram origem à fazenda haviam sido adquiridas em 1843 pelo pai de Custódio Guimarães, o primeiro barão (1854) - posteriormente (1867) visconde - do Rio Preto. Na segunda metade dos anos 1840, Guimarães pai investiu pesadamente na aquisição de escravos africanos (comprados no tráfico ilegal), no plantio de pés de café, e na construção da luxuosa sede de sua fazenda. Flores do Paraíso tornou-se o centro de um complexo de propriedades que, em 1868 (ano da morte do visconde do Rio Preto), englobava outras seis grandes fazendas que iam da fronteira das províncias do Rio de Janeiro com Minas Gerais até quase às margens do rio Paraíba, contando com mais de um milhar de escravos. A fazenda Flores do Paraíso se destacava tanto pelo seu vocabulário arquitetônico (casa de vivenda assobradada em estilo neoclássico, planta da sede em U conforme o modelo canônico da villa palladiana) quanto, em especial, pelo seu padrão técnico. A plantation foi uma das primeiras do Vale do Paraíba a adotar, ainda no começo da década de 1860, o maquinário Lidgerwood de beneficiamento do café em substituição aos antigos engenhos de pilões. ${ }^{8}$

Ao contrário do que ocorre com o açúcar, a cafeicultura é viável economicamente tanto em pequenas quanto em grandes propriedades. Dada a variação na estrutura de posse escrava e nas dimensões fundiárias das fazendas, não se pode assinalar um perfil preciso do que seria a unidade produtiva "típica" do Vale do Paraíba. Nessa região, houve de fato um número 
Neste detalhe do óleo de Facchinetti, observa-se à esquerda do complexo da sede uma grande edificação quadrangular, articulada aos dois terreiros de secar café (o primeiro, de terra, o segundo, de macadame) por uma construção cujo corpo projeta-se por um torreão no sobrepiso; nele, havia um relógio com sino; ao rés do chão, a passagem (separada por um portão) do pátio interno da construção quadrangular ao terreiro. Trata-se da senzala em quadra, um arranjo de moradia notavelmente próximo ao dos barracones cubanos, haja vista que marcado por entrada única, cubículos todos voltados a um pátio interno, e ausência de janelas externas. No caso da fazenda Flores do Paraíso, as janelas observadas na pintura de Facchinetti eram falsas, isto é, tratava-se de um recurso de trompe l'oeil inscrito na própria edificação que buscava conferir uniformidade visual ao conjunto arquitetônico da sede. ${ }^{9} \mathrm{~A}$ gênese desse arranjo de moradia se encontra no mesmo feixe de forças que levou à adoção dos barracones em Cuba: a conjuntura de questionamento à ordem escravista brasileira nas décadas de 1830 e 1840, em um momento no qual se montavam grandes fazendas inteiramente fundadas na importação massiva de africanos ilegalmente escravizados. A despeito de não serem construídas em alvenaria e estarem articuladas ao corpo das casas de vivenda monumentais, as senzalas em quadra do Vale do Paraíba obedeceram aos mesmos ditames de controle dos trabalhadores escravizados que deram origem aos barracones cubanos, fundados em rigorosos protocolos de confinamento. $E$, tal como nos engenhos cubanos, são esses preceitos de controle espacial que igualmente explicam o fato de megaproprietários como os Custódio Guimarães montarem várias fazendas contíguas, em vez de fundirem-nas em uma única plantation (Marquese, 2005: 175-185).

Ainda que o processo de produção do café não impusesse um ritmo equivalente à integração campo-manufatura que o açúcar exigia, as senzalas em quadra cumpriram papel importante para a coordenação do trabalho escravo no espaço e no tempo. A notável série de fotografias que Marc Ferrez compôs na última década da escravidão no Brasil bem o demonstra. Buscando atingir o público consumidor estrangeiro ávido pelas chamadas fotos souvenirs do mundo tropical, entre 1880 e 1885 Ferrez registrou as múltiplas situações que caracterizavam o trabalho escravo nas fazendas de café do Vale do Paraíba, um mundo que todos os coevos - inclusive os próprios senhores - sabiam estar condenado ao desaparecimento em médio ou curto prazo. Como bem denominou uma estudiosa recente dessa série, o impulso de Ferrez foi claramente ordenado pelo objetivo de tornar a escravidão "monumentalizada", equiparando "a força humana ao patrimônio construído" (Muaze, 2014: 163-182; ibidem, 2017). 


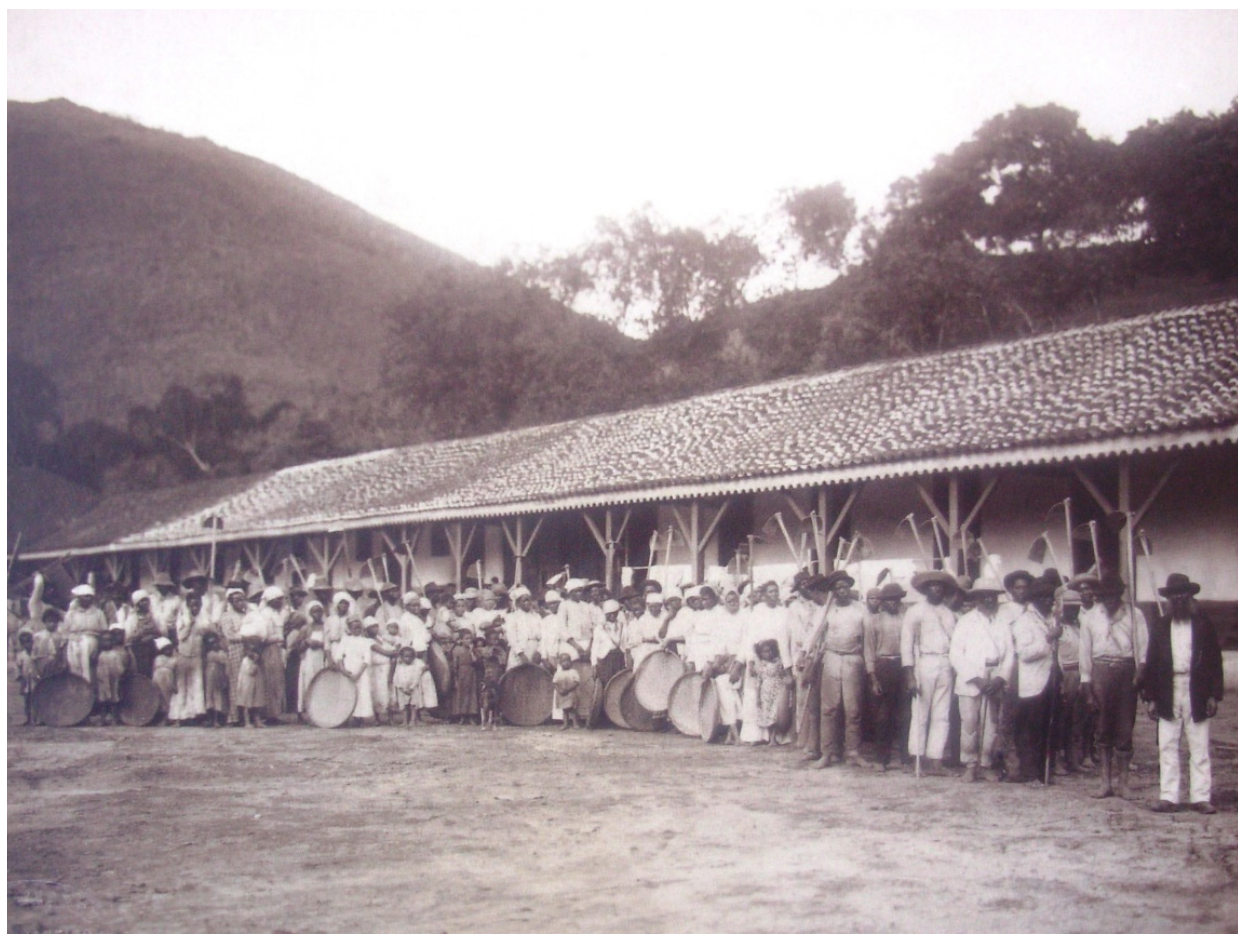

Figura 6: Marc Ferrez. Départ pour la cuillette du café, 1880. Acervo do Museu Afro-Brasil, São Paulo/SP.

É justamente esse caráter de "monumentalização" do projeto visual de Ferrez que o torna particularmente válido ao argumento deste artigo. Na figura 6, por exemplo, seu objetivo foi anotar visualmente a relação estreita entre a quadra da senzala e o terreiro de secagem do café, em um padrão de trabalho que era rigorosamente ordenado no tempo e no espaço. 0 local de moradia dos trabalhadores escravizados era, ao mesmo tempo, o principal local de beneficiamento do café: em torno da ou acoplados à quadra da senzala, eram dispostos os terreiros de secagem do café colhido, a casa dos engenhos que procediam à separação mecânica entre polpa/pergaminho e grãos, e as tulhas de armazenagem dos grãos beneficiados. A senzala em quadra atendia tanto ao objetivo de controlar a mobilidade noturna dos escravos quanto ao de comandar o trabalho coletivo deles. 0 agenciamento da quadra facilitava a coordenação de grupos numerosos de escravos por meio de procedimentos espaciais cotidianamente reiterados, dentre os quais o que vemos na foto, ou seja, a reunião dos escravos no terreiro logo após o nascer do sol para a inspeção e distribuição das tarefas do dia, ou, então, 0 trabalho repetitivo de revolvimento dos grãos de café para a secagem ao sol (Marquese, 2010: 96-98). 
Na esfera agrícola, a cafeicultura brasileira se destacou frente às suas rivais no Caribe (Jamaica, Cuba) e no espaço asiático (Java, Ceilão) pelo aumento crescente da taxa de exploração dos escravos, medida pela proporção de pés de café alocados a cada escravo adulto. Há vários registros qualitativos a respeito desse ponto na documentação do século XIX. A pesquisa recente de Breno Moreno (2013), contudo, conseguiu identificar quantitativamente esta tendência por meio do exame seriado de inventários post-mortem lavrados em Bananal (SP) entre as décadas de 1830 e 1860. Veja-se, a respeito, o gráfico a seguir.

\section{Gráfico 1: Evolução da exploração do trabalho escravo (em pés de café por escravo adulto). Bananal, 1830-1859}

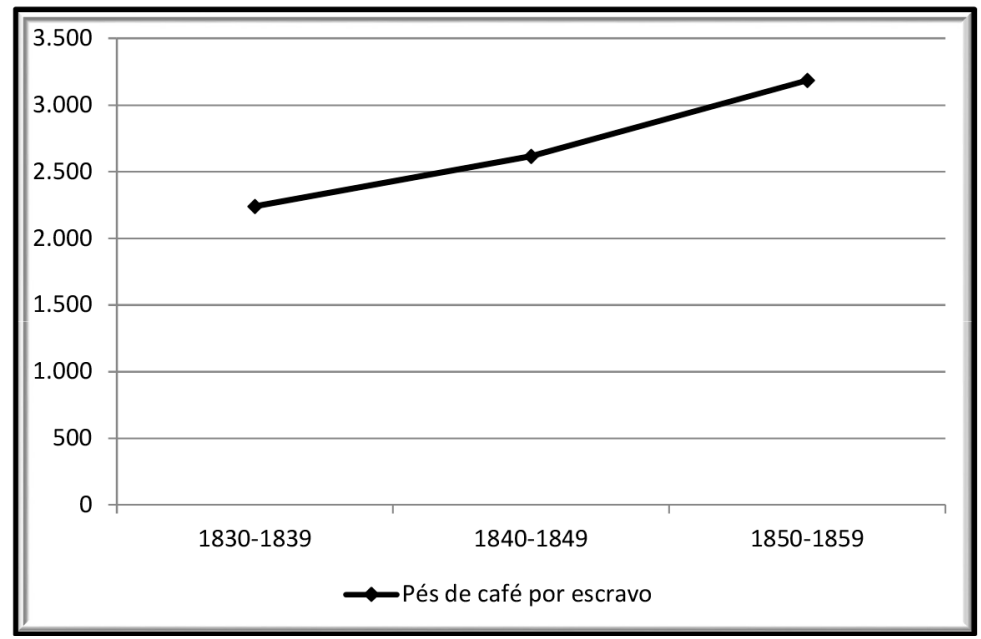

Fonte: Moreno, 2013: 223.

Como foi possível impor essa quantidade crescente de pés de café aos escravos? Uma vez mais, os novos mecanismos visuais de controle do trabalho escravo nos ajudam a entender a matéria. Os pés de café têm o caráter de bens de capital: uma vez em plena produção (o que demora cinco anos para ocorrer após o plantio inicial), eles produzem frutos por até duas décadas, exigindo como trato cultural apenas de duas a três capinas anuais. Na cafeicultura brasileira, essa atividade era organizada conforme o gang system clássico, isto é, trabalho coletivo feitorizado sob comando unificado: cada escravo era responsável por uma carreira entre os pés, devendo trabalhar em uníssono conforme os escravos mais rápidos, colocados nas pontas do cafezal, todos supervisionados por um feitor ou capataz. A novidade do Brasil consistiu na forma de disposição dos pés de café, com plantio alinhado da base ao topo dos morros de meia-laranja, e com grande afastamento entre as fileiras. Nesse sistema de plantio, 
havia uma quantidade muito menor de pés de café por área do que, por exemplo, no Caribe. O consequente desperdício de terreno no Brasil era mais do que compensado pelo fato de este sistema permitir fácil visualização da gang de escravos pelo feitor na base do morro e, consequentemente, a imposição de um número maior de pés de café por trabalhador (Marquese, 2008: 199-203; ibidem, 2010: 104-109).

As lentes de Marc Ferrez captaram magnificamente essa técnica. Na figura 7, os escravos estão concentrados em algumas poucas linhas por razões da composição fotográfica, mas o que se vê aí é uma turma de trabalhadores em um típico cafezal do Vale do Paraíba, aberto o suficiente de modo a permitir sua imediata observação para quem estivesse afastado do morro de meia-laranja.

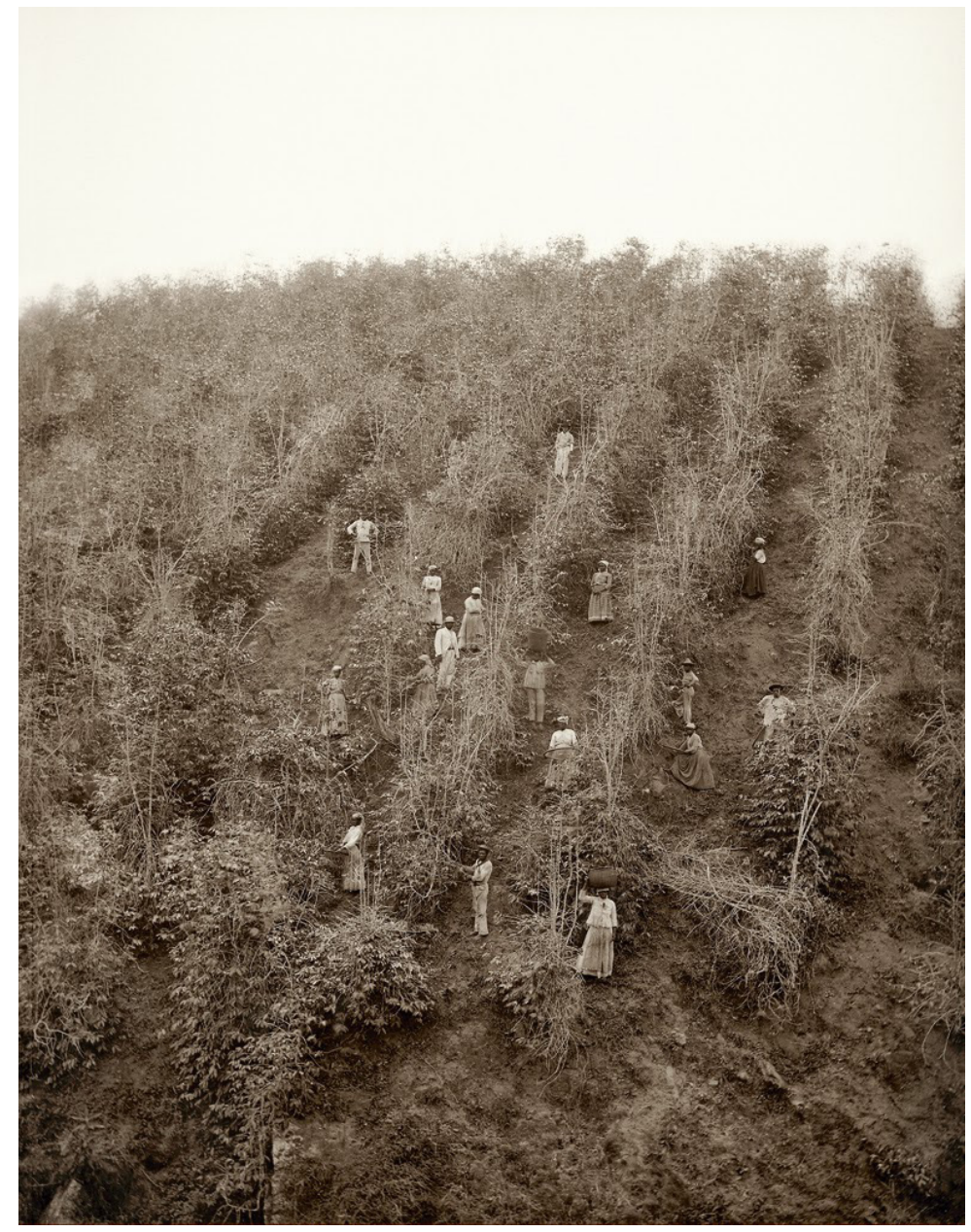

Figura 7: Marc Ferrez. Escravos na colheita de café, 1882 (Acervo do Instituto Moreira Salles, Rio de Janeiro/RJ). 
A atividade na qual os escravos estavam envolvidos no momento em que Ferrez os representou não era a capina, mas a colheita: os pés de café desnudos bem o demonstram. Aqui, chegamos ao ponto final da análise. Mais pés de café por trabalhador significavam mais grãos a serem colhidos por escravo na época da safra - os cafezais brasileiros, aliás, destacavam-se também por sua maior produtividade. No entanto, em razão da variação bianual das safras no Brasil (algo comum quando os cafeeiros são plantados a pleno sol, sem sombreamento), era impossível à gerência escravista ter ciência prévia do volume a ser colhido. Em anos ruins, a força de trabalho disponível na fazenda dava conta facilmente da colheita, mas, em anos bons, a pressão sobre os trabalhadores aumentava. A solução adotada no Vale do Paraíba se aproximou notavelmente da prática do Sul algodoeiro, ou seja, um sistema de tarefas individualizado, variável conforme a avaliação sobre o andamento da safra e a capacidade de cada trabalhador, e que o compelia a colher a maior quantidade possível de produto sob o risco de ser punido fisicamente caso não cumprisse a cota mínima estipulada, recebendo prêmio monetário correspondente ao montante extra, caso a ultrapassasse. ${ }^{10}$

0 que tudo isso significava em termos de sobretrabalho para os escravos foi bem anotado pelo jornalista britânico G. A. Crüwell, que veio ao Brasil na década de 1870, a mando dos cafeicultores do Ceilão, com o objetivo de descobrir os segredos da enorme eficiência da produção brasileira. De acordo com ele,

0 trabalho exigido e executado pelos escravos é enorme. Está além do máximo do que os seres humanos são capazes de realizar sem destruir os recursos físicos do indivíduo. No Brasil, um escravo é obrigado a colher, na safra, 12 bushels de café por dia, enquanto no Ceilão dois bushels são a tarefa do coolie; embora se pague qualquer coisa além dessa tarefa, e o coolie possa trazer um ou dois bushels a mais, e a colheita de apenas frutas maduras seja um trabalho mais difícil no Ceilão do que a derriça no solo (incluindo terra e pedras) e uma colheita indiscriminada das bagas nas plantações brasileiras, quatro alqueires no Ceilão é o máximo que um coolie é capaz de fazer, e nada mais. (Crüwell \& Blacklaw, 1876: 18-19; tradução livre.)

Noutras palavras, era impossível aos trabalhadores coolies do Ceilão competirem com o montante de trabalho extraído dos escravos do Brasil, obtido a partir de um sistema de gestão fundado na estrita visualização dos escravos, no campo, na sede, nos terreiros. E, tal como o que ocorreu na produção açucareira de Cuba, essa nova visualidade é crucial para se compreender o domínio que o Vale do Paraíba exerceu sobre o mercado mundial do café nos tempos da segunda escravidão. 


\section{NOTAS}

1 Uma das poucas exceções é a "contra-história da visualidade" de um dos principais expoentes no campo da cultura visual (Mirzoeff, 2011: 48-76). Esse livro, no entanto, contém sérios problemas, a começar por sua definição anistórica e abstrata do que seja a "visualidade" e a "contravisualidade". Tal enquadramento o conduz a um tratamento igualmente anistórico - e muito simplificador - da organização visual da plantation escravista do Caribe francês.

2 Cf. The Trans-Atlantic Slave Trade Database (TSTD). Disponível em: http://www.slavevoyages.org.

3 Há uma excelente edição crítica (García Mora e Santamaria García, 2006). Todas as imagens de Laplante usadas neste artigo foram retiradas desta edição, a cujos organizadores agradeço pela gentileza em cedê-las para reprodução. Veja-se, também, Venegas, 1996.

4 Ver, em especial, o modelo proposto pela Cartilla práctica..., 1862.

5 Veja-se, por exemplo, a recomendação da Cartilla práctica..., 1862: 18: "el batey de un ingenio debería colocarse en el centro de las 49 caballerías de tierra que se han destinado desde un principio para campo de caña, a no ser que hubiese algún accidente que lo impidiera, a fin de acortar en todo lo posible las distancias, cuestión de mucha importancia para hacer el tiro de la caña con facilidad, brevedad y economía posibles". 0 ingenio Merced, aliás, pareceu seguir de perto as proporções recomendadas neste manual: 40 caballerías com cana (e mais 4 para guardarrayas/batey e 5 para produção de mantimentos), força de trabalho com cerca de 320 trabalhadores, e moenda a vapor com 5 trens jamaicanos, capazes de produzir 117.300 arrobas de açúcar.

6 Ver os modelos de controle fornecidos por Landa, 1866: 60-61.

7 A respeito desta pintura de Facchinetti, ver Marquese (2007). Na p. 217 deste artigo, há uma reprodução dela: http://www.revistas.usp.br/rieb/article/view/34562/37300.

8 Museu da Justiça do Estado do Rio de Janeiro. Inventário - Visconde do Rio Preto, 1869. Cartório do $1^{\circ}$ Ofício de Valença, Rio de Janeiro.

9 A técnica de pintura parietal em trompe l'oeil na fachada externa de senzalas pode ser observada ainda hoje em uma fazenda relativamente próxima a Flores do Paraíso, a fazenda Santa Clara, localizada no município de Santa Rita do Jacutinga, Minas Gerais. Ver, a respeito, as fotografias contidas no caderno de imagens de Marquese (2004, imagens 11 a 13), e Salles (2008, imagem 19).

10 A melhor descrição contemporânea desse sistema está em Andrade, 1989: 108-111. Sobre o Sul algodoeiro, ver Baptist, 2014: 111-144. 


\section{REFERÊNCIAS BIBLIOGRÁFICAS}

ARAÚJO, Ana Lucia. Public Memory of Slavery: Victims and Perpetrators in the South Atlantic. Amherst: Cambria Press, 2010.

Shadows of the Slave Past: Memory, Heritage, and Slavery. Nova York: Routledge, 2014.

ARRUDA, José Jobson de Andrade. A produção econômica. In: NIZZA DA SILVA, Maria Beatriz (org.). Nova história da expansão portuguesa. O Império Luso-Brasileiro (1750-1822). Lisboa: Estampa, 1986.

ANDRADE, Eloy. 0 Vale do Paraíba. Rio de Janeiro: Real Gráfica, 1989.

BAPTIST, Edward E. The Half Has Never Been Told. Slavery and the Making of American Capitalism. Nova York: Basic Books, 2014.

BARCIA PAZ, Manuel. Seeds of Insurrection: Domination and Resistance in Western Cuban Plantations, 18081848. Baton Rouge: Louisiana State University Press, 2008.

BECKERT, Sven. Empire of Cotton. A Global History. Nova York: Alfred Knopf, 2014.

BELTRAMIN, Fabiana. Sujeitos iluminados. A reconstituição das experiências vividas no estúdio de Christiano Jr. São Paulo: Alameda, 2013.

BLACKBURN, Robin. The American Crucible. Slavery, Emancipation and Human Rights. Londres: Verso, 2011.

BONNET, Natacha. L'Organisation du travail servile sur la sucrerie domingoise au XVIIle siécle". In: HRODES, P. (org.) L'Esclave et les plantations de l'établissement de la servitude à son abolition. Hommage à Pierre Pluchon. Rennes: Presses Universitaires de Rennes, 2008.

CANTERO, Justo G. Los ingenios: Colección de vistas de los principales ingenios de azúcar de la isla de Cuba. Madri: Mapfre/Tavera - Doce Calles - CSIC, 2006.

CARTILLA PRACTICA del manejo de ingenios ó fincas destinadas á producir azúcar, escrita por un montuno. Irun: Imprenta de la Elegancia, 1862.

CAUNA, Jacques. Vestiges of the Built Landscape of Pre-Revolutionary Saint-Domingue. In: GEGUS, David Patrick; FIERING, Norman. The World of the Haitian Revolution. Bloomington: Indiana University Press, 2009. p. 21-48.

CRÜWELL, G. A.; BLACKLAW, A. Scott. Brazil as a Coffee Growing Country: its Capabilities, the Mode of Cultivation, and Prospects of Extension, Described in a Series of Letters. Colombo: A.M. \& J. Ferguson, 1876.

DAL LAGO, Enrico. American Slavery, Atlantic Slavery, and Beyond. The U.S. "Peculiar Institution" in International Perspective. Boulder: Paradigm Publishers, 2012.

DRESSER, Madge; HANN, Andrew (ed.). Slavery and the British Country House. Swindon: English Heritage, 2013.

ELLIS, Clifton; GINSBURG Rebecca (org.). Architecture and Landscapes of North American Slavery. New Haven: Yale University Press, 2010.

FUNES, Reinaldo; TOMICH, Dale. Naturaleza, tecnología y esclavitud en Cuba: frontera azucarera y Revolución Industrial, 1815-1870. In: PIQUERAS, José Antonio (org.) Trabajo libre y trabajo coactivo en sociedades de plantación. Madri: Siglo XXI, 2009. p.75-117. 
GARCÍA MORA, Luis Miguel; SANTAMARIA GARCÍA, Antonio. Donde cristaliza la esperanza: lectura de Los ingenios. In: CANTERO. Justo G. Los ingenios. Colección de vistas de los principales ingenios de azúcar de la isla de Cuba. Madri: Mapfre/Tavera - Doce Calles - CSIC, 2006.

GIKANDI, Simon. Slavery and the Culture of Taste. Princeton: Princeton University Press, 2011.

GRINBERG, Keila; SALLES, Ricardo; BORGES, Magno Fonseca. Rebeliões escravas antes da extinção do tráfico. In: i. O Brasil imperial. Rio de Janeiro: Civilização Brasileira, 2009. V. I - 1808-1831, p. 235-270.

GOMES, Flávio dos Santos. Histórias de quilombolas. Mocambos e comunidades de senzalas no Rio de Janeiro, século XIX. São Paulo: Companhia das Letras, 2006.

HIGMAN, B.W. Slave Populations of the British Caribbean, 1807-1834. Mona: University of the West Indies Press, 1995.

INSTITUTO BRASILEIRO DE GEOGRAFIA E ESTATÍSTICA (IBGE). Estatísticas históricas do Brasil. Rio de Janeiro: IBGE, 1987.

JOHNSON, Walter. River of Dark Dreams. Slavery and Empire in the Cotton Kingdom. Cambridge, MA: Harvard University Press, 2013.

KAYE, Anthony. The Second Slavery: Modernity in the Nineteenth-Century South and the Atlantic World. Journal of Southern History, v.73, n. 3, p. 627-50, ago. 2009.

KOUTSOUKOS, Sandra Sofia Machado. Negros no estúdio do fotógrafo. Brasil, segunda metade do século XIX. Campinas: Editora Unicamp, 2010.

KRIZ, Kay Dian. Slavery, Sugar, and the Culture of Refinement. Picturing the British West Indies, 1700-1840. New Haven: Yale University Press, 2008.

LANDA, Antonio. El administrador del ingenio. Havana: Imp. La Fortuna, 1866.

LIMA, Valéria. J.-B. Debret, historiador e pintor. A viagem pitoresca e histórica ao Brasil (1816-1839). Campinas: Editora Unicamp, 2007.

MARQUES, Leonardo. The United States and the Transatlantic Slave Trade to the Americas, 1776-1867. New Haven: Yale University Press, 2016.

MARQUESE, Rafael de Bivar. Feitores do corpo, missionários da mente. Senhores, letrados e o controle dos escravos nas Américas, 1660-1860. São Paulo: Companhia das Letras, 2004.

. Moradia escrava na era do tráfico ilegal: senzalas rurais no Brasil e em Cuba, c.1830-1860. Anais do Museu Paulista. História e Cultura Material, USP, Nova Série, v. 13 , n. 2, p. 165-188, 2005.

A paisagem da cafeicultura na crise da escravidão: as pinturas de Nicolau Facchinetti e Georg Grimm. Revista do IEB, n. 44 p. 55-76, fev. 2007. Disponível em: http://www.revistas.usp.br/rieb/article/ view/34562/37300. Acesso em: 18 de janeiro de 2018.

. African Diaspora, Slavery, and the Paraiba Valley Coffee Plantation Landscape: XIXth Century Brazil. Review, A Journal of the Fernand Braudel Center, v. 31, n. 2, p. 195-216, 2008.

Espacio y poder en la caficultura esclavista de las Américas: el Valle del Paraíba en perspectiva comparada, 1750-1850. In: PIQUERAS, José Antonio (org.) Trabajo libre y trabajo coactivo en sociedades de plantación. Madri: Siglo XXI, 2009. p.215-252. 
0 Vale do Paraíba cafeeiro e o regime visual da segunda escravidão: o caso da fazenda Resgate. Anais do Museu Paulista, v. 18, n. 1, p. 83-128, jan.-jun. 2010.

Capitalismo, escravidão e a economia cafeeira do Brasil no longo século XIX. Saeculum, n. 29, p. 289-321, jul.-dez. 2013.

; TOMICH, Dale. O Vale do Paraíba escravista e a formação do mercado mundial do café no século XIX.. In: GRINBERG, K.; SALLES, R. (org.) O Brasil imperial. Rio de Janeiro: Civilização Brasileira, 2009. V. II 1831-1870, p. 339-383.

; PARRON, Tâmis; BERBEL, Márcia. Slavery and Politics. Brazil and Cuba, c.1790-1850. Albuquerque: The University of New Mexico Press, 2016.

; SALLES, Ricardo (org.). Escravidão e capitalismo histórico no século XIX: Cuba, Brasil e Estados Unidos. Rio de Janeiro: Civilização Brasileira, 2016.

MARTINS, Carlos; PICCOLI, Valéria (org.) Facchinetti. Rio de Janeiro: Centro Cultural Banco do Brasil, 2004.

McINNIS, Maurie D. The Politics of Taste in Antebell $m$ Charleston. Chapel Hill: The University of North Carolina Press, 2005.

Slaves Waiting for Sale. Abolitionist Art and the American Slave Trade. Chicago: The University of Chicago Press, 2012.

MIRZOEFF, Nicholas. The Right to Look. A Counterhistory of Visuality. Durham: Duke University Press, 2011.

MORENO, Breno Aparecido Servidone. Demografia e trabalho escravo nas propriedades rurais cafeeiras de Bananal, 1830-1860. 2013. Dissertação (Mestrado em História Social) - Universidade de São Paulo, São Paulo. 2013.

MORENO FRAGINALS, Manuel. O engenho: complexo socioeconômico açucareiro cubano. São Paulo: Hucitec, 1989. 2v.

MORGAN, Philip D. Task and Gang Systems. The Organization of Labor on New World Plantations. In: INNES, S. (org.). Work and Labor in Early America. Chapel Hill: University of North Carolina Press, 1988. p. 189-220.

MUAZE, Mariana. A escravidão no Vale do Paraíba pelas lentes do fotógrafo Marc Ferrez (1880-1885). In: CARVALHO, J. M.; BASTOS, L. (org.) Dimensões e fronteiras do Estado brasileiro no século XIX. Rio de Janeiro: Eduerj, 2014. p.163-182.

Violência apaziguada: escravidão e cultivo do café nas fotografias de Marc Ferrez (1882-1885). Revista Brasileira de História (online), v. 74, p. 1-20, 2017.

PARRON, Tâmis. A política da escravidão na era da liberdade. Estados Unidos, Brasil e Cuba, 1787-1846. 2015. Tese (Doutorado em História Social) - Universidade de São Paulo, São Paulo. 2015.

PIQUERAS, José Antonio. Islas de azúcar y de esclavos. In: (org.). Historia comparada de las Antillas. Madri: Ediciones Doce Calles, 2014a.

- Reordenando el universo azucarero. Del emporio de Saint-Domingue a la segunda esclavitud. In: (org.). Historia comparada de las Antillas. Madri: Ediciones Doce Calles, 2014b.

QUILLEY, Geoff; KRIZ, Kay Dian (org.). An Economy of Colour. Visual Culture and the Atlantic World, 16601830. Manchester: Manchester University Press, 2003. 
RIBAS, Rogério de Oliveira. Tropeirismo e escravidão: um estudo das tropas de café das lavouras de Vassouras, 1840-1888. 1989. Dissertação (Mestrado em História) - Universidade Federal do Paraná, Curitiba. 1989.

ROOD, Daniel B. The Reinvention of Atlantic Slavery. Technology, Labor, Race, and Capitalism in the Greater Caribbean. Oxford: Oxford University Press, 2017.

SALLES, Ricardo. E o vale era o escravo. Vassouras, século XIX. Senhores e escravos no coração do Império. Rio de Janeiro: Civilização Brasileira, 2008.

SAMPER, Mario; FERNANDO, Radin. Historical statistics of coffee production and trade from 1700 to 1960. In: CLARENCE-SMITH, W. G.; TOPIK, S. (org.). The Global Coffee Economy in Africa, Asia, and Latin America, 1500-1980. Cambridge: Cambridge University Press, 2003.

SANTOS, Ynaê Lopes dos. Irmãs do Atlântico. Escravidão e espaço urbano no Rio de Janeiro e Havana (17631844). 2012. Tese (Doutorado em História Social) - Universidade de São Paulo, São Paulo. 2012.

SCHMIDT-NOWARA, Christopher. Slavery, Freedom, and Abolition in Latin America and the Atlantic World. Albuquerque: University of New Mexico Press, 2011.

SCHWARTZ, Stuart B. Segredos Internos. Engenhos e escravos na sociedade colonial (1550-1835). São Paulo: Companhia das Letras, 1988.

SELA, Eneida Maria Mercadante. Modos de ser, modos de ver. Viajantes europeus e escravos africanos no Rio de Janeiro (1808-1850). Campinas: Editora Unicamp, 2008.

SILVA Jr., Waldomiro Lourenço da. Entre a escrita e a prática: direito e escravidão no Brasil e em Cuba, c.17601871. 2015. Tese (Doutorado em História Social) - Universidade de São Paulo, São Paulo. 2015.

SLENES, Robert W. African Abrahams, Lucretias and Men of Sorrows: Allegory and Allusion in the Brazilian Anti-Slavery Lithographs (1827-1835) of Johann Moritz Rugendas. Slavery \& Abolition, v. 23, n. 2, p. 147-168, 2002.

TOMICH, Dale W. Through the Prism of Slavery. Labor, Capital, and World Economy. Boulder, CO: Rowman \& Littlefield Publ., 2004.

TOMICH, Dale. The Invention of the Cuban Sugar Mill: Space, Time, and Labor Management. In: GONZÁLEZ-RIPOLL, M. D.; ÁLVARES CUARTERO, I. (org.). Francisco Arango y la invención de la Cuba azucarera. Salamanca: Ediciones Universidad de Salamanca, 2009. p.133-150.

VENEGAS, Carlos. El libro de los ingenios. In: CUELLO, A. M. (org.). Agua, trabajo y azúcar. Actas del VI Seminario Internacional de Caña de Azúcar. Granada: Diputación Provincial de Granada, 1996.

VLACH, John Michael. The Planter's Prospect. Privilege \& Slavery in Plantation Paintings. Chapel Hill: The University of North Carolina Press, 2002.

WOOD, Marcus. Blind Memory. Visual Representations of Slavery in England and America, 1780-1865. Manchester: Manchester University Press, 2000.

WOOD, Marcus. Black Milk. Imagining Slavery in the Visual Cultures of Brazil and America. Oxford: Oxford University Press, 2013.

ZAYAS, Andres de. Observaciones sobre los ingenios de esta isla. Memorias de la Real Sociedad Patriótica de La Habana, v. 12, n. 3, p. 174-183, jan. 1836. 